\title{
Identification and Characterization of Forced Degradation Products of Moexipril Using LC-ESI-MS/Q-TOF
}

Rajesh Babu KB ${ }^{1,2,{ }^{*}}$, Nagaraju $\mathbf{P}^{2}$, Rajendra ${ }^{2,3}$, Gowri Sankar $\mathbf{D}^{1}$, Seshagiri Rao JVLN ${ }^{1}$, Jayathirtha Rao $\mathbf{V}^{2}$ and Srinivas $\mathbf{R}^{4}$

${ }^{1}$ Department of Pharmaceutical Analysis and Quality Assurance, Andhra University, Visakhapatnam, India

${ }^{2}$ CPC Division, Indian Institute of Chemical Technology, Hyderabad, India

${ }^{3}$ Vellore Institute of Technology, Vellore, India

${ }^{4}$ National Centre for Mass Spectrometry, Indian Institute of Chemical Technology, Hyderabad, India

"Corresponding author: Rajesh Babu KB, Department of Pharmaceutical Analysis and Quality Assurance, Andhra University, Visakhapatnam, India, Tel: +919490597959; E-mail: kbrajeshbabu@gmail.com

Received Date: Jun 07, 2018; Accepted Date: Jun 25, 2018; Published Date: Jul 03, 2018

Copyright: ( 2018 Babu KBR, et al. This is an open-access article distributed under the terms of the Creative Commons Attribution License, which permits unrestricted use, distribution, and reproduction in any medium, provided the original author and source are credited.

\begin{abstract}
A forced degradation study on drug moexipril has been conducted to provide an insight into degradation products and degradation pathways as per International Conference on harmonization (ICH) Q1A (R2) guideline. Moexipril was subjected to stress conditions by hydrolysis (acidic, alkaline and neutral), oxidation, photolysis and thermal. The drug degraded in the stress conditions of hydrolysis, oxidation and photolysis but remained stable in conditions of thermal stress. A total of 5 degradation products were formed from the drug, which were separated by developed gradient liquid chromatographic method on a C-18 column $(4.6 \times 150 \mathrm{~mm}, 5 \mu \mathrm{m})$ by gradient elution technique using ammonium acetate buffer and methanol at mobile phase flow rate of $1.0 \mathrm{~mL} / \mathrm{min}$ at $25^{\circ} \mathrm{C}$. The degradation products were identified and structurally elucidated by using liquid chromatography with quadrupole time of flight electrospray ionization tandem mass spectrometer combined accurate mass measurements. The most probable structures for the observed degradation products were assigned by comparing the product ions of all the protonated degradation products with the product ions of protonated moexipril.
\end{abstract}

Keywords: Moexipril; LC-ESI-MS; Degradation products; Characterization

\section{Abbreviations \\ MOX: Moexipril; DP: Degradation Product}

\section{Introduction}

Forced degradation studies on drug substances and drug products helps to provide insight into the degradation products (DPs) and degradation pathways. Structural elucidation of degradation products is essential during the stage of pharmaceutical drug discovery and development. Therefore it is indispensable to carry out stability testing of drugs under different stress conditions as per guidelines of International Conference on harmonization (ICH) and other International Agencies [1-3].

Moexipril (MOX) is an Antihypertensive drug belongs to a category of Angiotensin converting enzyme (ACE) inhibitor. MOX is a prodrug of Moexiprilat, which acts by inhibiting Angiotensin converting enzyme in humans and animals. MOX is metabolized in the liver to form pharmacologically active compound Moexiprilat, which blocks the conversion of Angiotensin I to Angiotensin II. Blockage of Angiotensin II limits hypertension within the vasculature. Additionally, MOX has been found to possess cardioprotective properties $[4,5]$. According to IUPAC, nomenclature of MOX is (3S)-2[(2S)-2-\{[(2S)-1-ethoxy-1-oxo-4-phenylbutan-2-

yl]amino\}propanoyl]-6,7-dimethoxy-1,2,3,4-tetrahydroisoquinoline-3carboxylic acid (Figure 1).

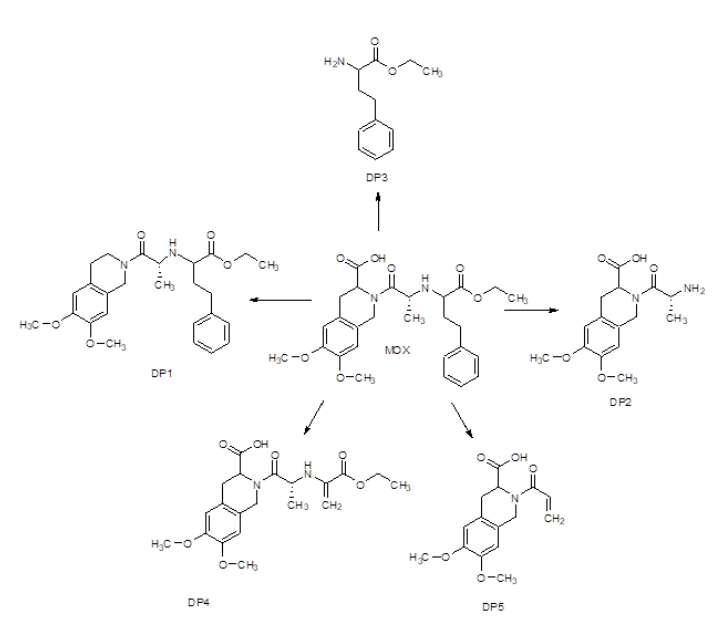

Figure 1: Proposed structures of DPs formed under various stress conditions.

A.A. Elshanawane et al. have reported a stability indicating reversed-phase liquid chromatographic method for determination of ramipril and MOX in the presence of their degradation products [6]. Koti et al. reported a liquid chromatography-electrospray ionization mass spectrometry (LC-ESI-MS) method for simultaneous analysis of MOX and Moexiprilat in biological samples [7]. Hammes et al. also reported a gas chromatography-negative Ion chemical ionization mass spectrometry (GC-NICI-MS) for simultaneous analysis of MOX and 
Page 2 of 6

Moexiprilat, in human plasma [8]. Karraa et al. developed a rapid and sensitive liquid chromatography-tandem mass spectrometric assay for MOX in human plasma [9]. As there are no reports available on the degradation behavior, identification and characterization of Degadaation Products (DPs) of MOX formed under various stress conditions, we have carried out a detailed study on stability indicating LC-MS/MS method for MOX.

\section{Materials and Methods}

\section{Chemicals and reagents}

MOX reference standard was obtained from pharmaceutical manufacturing unit, Baroda, India. HPLC grade methanol was purchased from Merck Specialities (Mumbai, India). Ultra-pure water was obtained by Millipore Milli-Q plus purification system. Analytical reagent grade ammonium acetate, formic acid, sodium hydroxide, hydrochloric acid and hydrogen peroxide were purchased from S.D Fine chemicals (Mumbai, India).

\section{Equipments and apparatus}

LC studies were performed on a high performance liquid chromatography from Agilent 1200 series (Agilent Technologies, USA) equipped with a Quaternary pump, an online degasser, a diode-array detector, an auto sampler, a column oven and a computer system under control of Chemstation software. The samples were separated on a Agilent XBD, C-18 column $(150 \mathrm{~mm} \times 4.6 \mathrm{~mm} \times 5 \mu \mathrm{m}$ particle size $)$.

For LC-MS studies, an Agilent 1200 series HPLC instrument ( Agilent Technologies, USA) coupled to a Quadrupole time-of-flight (Q-TOF) mass spectrometer (Q-TOF LC/MS 6510 series classic, Agilent Technologies, USA) equipped with ESI source was used. The software used was Mass Hunter workstation.

Hydrolytic degradation studies were performed in a oil bath equipped with temperature controller (Heidolph, Germany). Photolytic degradation studies were carried out in a photostability chamber (Mack equipment, MK-10-PH, $230 \mathrm{~V}$ Phase). Other equipments used were a pH-meter (Elico LI-120, Schwerzenbach, Switzerland), Analytical balance (Schimadzu, Kyoto, Japan) and micropipettes (Eppendorf, Hamburg, Germany).

\section{Forced degradation studies}

Forced degradation studies of MOX were carried out to determine stability by knowing degradation pathways for identification of likely degradation products as per ICH guidelines Q1A (R2).

Amount of about $10.0 \mathrm{mg}$ of MOX was subjected to stress hydrolytic degradation under acidic, basic and neutral conditions by refluxing with $10.0 \mathrm{~mL}$ of $0.1 \mathrm{~N} \mathrm{HCl}, 0.1 \mathrm{~N} \mathrm{NaOH}$, and $\mathrm{H}_{2} \mathrm{O}$ at $80^{\circ} \mathrm{C}$ for 48 hours, 48 hours, and 72 hours, respectively. The oxidative degradation of the drug was carried out using $3 \%, 6 \%, 30 \% \mathrm{H}_{2} \mathrm{O}_{2}$ for about 7 days. The thermal stress was carried out by spreading the drug to about 1.0 $\mathrm{mm}$ thickness over the petridish and kept for 3 days at $100^{\circ} \mathrm{C}$. The photolytic stress studies were performed by exposing the solid and liquid forms of MOX to UV light at $320 \mathrm{~nm}$ for 10 days. All the obtained forced degraded samples are preserved in refrigerator at $5^{\circ} \mathrm{C}$.

\section{Preparation of sample for HPLC and LC-MS analysis}

The stressed samples of MOX were diluted 10 times with mobile phase before injection into the HPLC. All the samples were purified by filtration through $0.22 \mu \mathrm{m}$ membrane filter before HPLC and LC-MS analysis.

\section{Results and Discussion}

\section{Optimization of LC-MS conditions}

The main objective of this work was to develop liquid chromatography method to separate all degradation products from moexipril and degradation products from each other under various stress conditions. Agilent XBD, C-18 column $(150 \mathrm{~mm} \times 4.6 \mathrm{~mm} \times 5$ $\mu \mathrm{m}$ particle sizes) was found suitable for this chromatographic separation after tried with different columns. During initial separation trails methanol/water, methanol/ammonium acetate buffer solution $(10 \mathrm{mM}, \mathrm{pH}$ adjusted to $6.0 \pm 0.5)$ in different proportions were adopted as a mobile phase using isocratic modes, but the separation of MOX and its DPs were not optimum. The resolution of MOX and its DPs was influenced by the concentration of ammonium acetate buffer in the mobile phase. The peaks were merged at $10 \mathrm{mM}$ ammonium acetate ( $\mathrm{pH}$ 6.0). While there was improvement in the resolution at 20 $\mathrm{mM}$ ammonium acetate ( $\mathrm{pH}$ 6.0). Finally we achieved a good resolution of peaks with acceptable shape with mobile phase consisting of $20 \mathrm{mM}$ ammonium acetate buffer (A), pH adjusted to 6.0 using dilute formic acid and methanol (B) in a gradient elution program. The gradient program for mobile phase solvents was set as follows, $\left(\mathrm{T}_{\mathrm{min}} /\right.$ $\%$ solution of $\mathrm{B}){ }_{0-0} / 30,{ }_{0-5} / 65,{ }_{5-15} / 65,{ }_{15-20} / 30$. The mobile phase flow rate of $1.0 \mathrm{ml} / \mathrm{min}$, column temperature of $25^{\circ} \mathrm{C}$ and wavelength of 273 $\mathrm{nm}$ were found to be suitable for the chromatographic separation of MOX and its DPs.

The ESI source conditions were optimized for good signal and high sensitivity. The operating source conditions for MS scan of MOX in positive ESI mode were optimized as follows; the fragmentor voltage at $80 \mathrm{~V}$; the capillary at $3000-3500 \mathrm{~V}$; the skimmer at $60 \mathrm{~V}$; high purity nitrogen was used as nubulizing (45 psi) and auxiliary gas; In experiments of collision induced dissociation (CID), MS1 was kept static, quadrupole analyzer was used selecting the precursor ion of interest and time-of-flight (TOF) analyzer was used for analyzing the product ions. Spectra were recorded with an average of 20-25 scans under identical experimental conditions.

\section{Degradation behavior}

The optimized LC-MS method is applicable to identify DPs. The LC-ESI-MS total ion chromatograms (TIC) of unreacted MOX are shown in (Figure 2a). The drug formed 4 DPs, DP1, DP2, DP4 and DP5 under acidic conditions (Figure 2b). Three DPs, DP2, DP3 and DP4 were formed under basic conditions (Figure 2c). The drug showed DP1, DP4 and DP5 under neutral and oxidative stress conditions (Figure $2 \mathrm{~d}$ and 2e). Two DPs, DP4 and DP5 were formed under photolytic stress conditions (Figure 2f). No DPs were formed under thermal stress conditions. All these degradation products have been structurally elucidated by using LC-MS/MS combined with accurate mass measurements. The proposed structures of DPs and their elemental compositions are given in Figure 1 and Table 1, respectively. 
Citation: Babu KBR, Nagaraju P, Rajendra, Sankar DG, Rao JVLNS, et al. (2018) Identification and Characterization of Forced Degradation Products of Moexipril Using LC-ESI-MS/Q-TOF. Biochem Anal Biochem 7: 356. doi:10.4172/2161-1009.1000356

Page 3 of 6

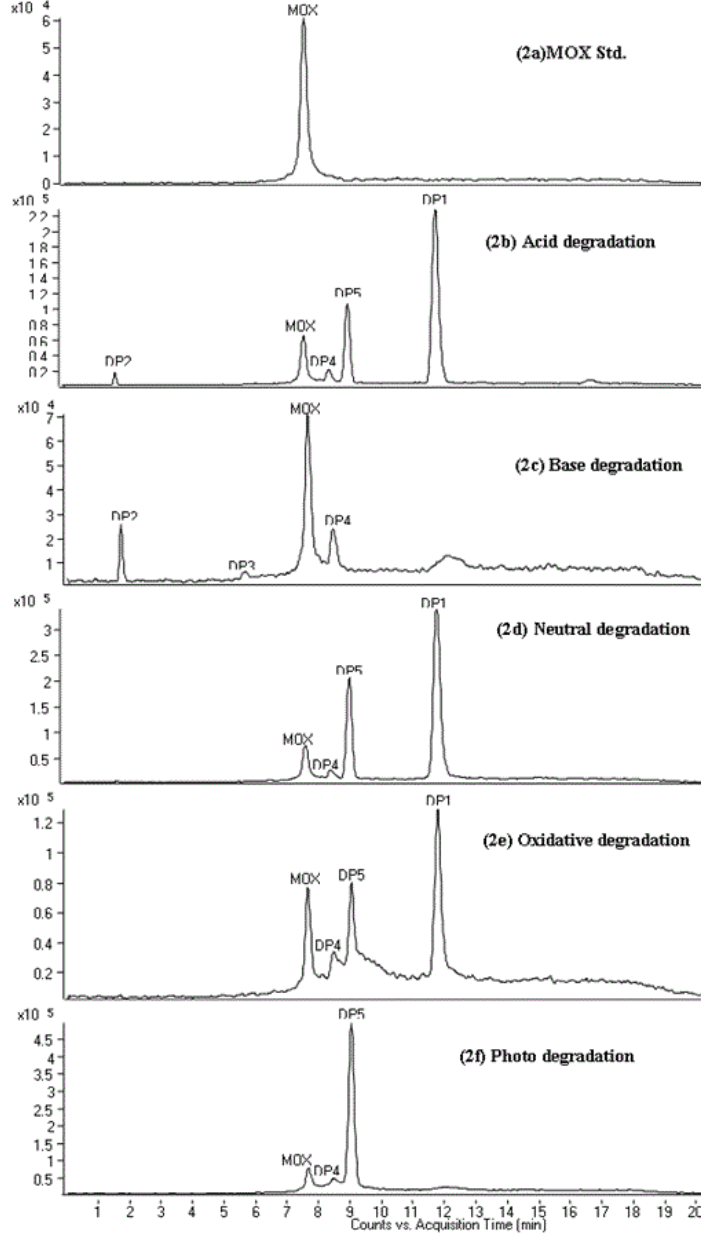

Figure 2: (a) LC-ESI-MS-TIC of MOX std., (b) LC-ESI-MS-TIC of acid degradation products, (c) LC-ESI-MS-TIC of base degradation products, (d) LC-ESI-MS-TIC of neutral degradation products, (e) LC-ESI-MS-TIC of oxidative degradation products, (f) LC-ESI-MSTIC of photolytic degradation products.

\begin{tabular}{|c|c|c|c|c|}
\hline $\begin{array}{l}\text { MOX and } \\
\text { DPs }\end{array}$ & $\begin{array}{l}\text { Proposed } \\
\text { formula }\end{array}$ & $\begin{array}{l}\text { Observed } \\
\text { mass (Da) }\end{array}$ & $\begin{array}{l}\text { Calculated } \\
\text { mass (Da) }\end{array}$ & Error (Da) \\
\hline \multirow{10}{*}{ MOX } & $\mathrm{C}_{27} \mathrm{H}_{35} \mathrm{~N}_{2} \mathrm{O}_{7}$ & 499.2434 & 499.2444 & -0.0010 \\
\hline & $\mathrm{C}_{26} \mathrm{H}_{35} \mathrm{~N}_{2} \mathrm{O}_{5}$ & 455.2543 & 455.2546 & -0.0003 \\
\hline & $\mathrm{C}_{15} \mathrm{H}_{21} \mathrm{~N}_{2} \mathrm{O}_{5}$ & 309.1441 & 309.1450 & -0.0009 \\
\hline & $\mathrm{C}_{15} \mathrm{H}_{18} \mathrm{NO}_{5}$ & 292.1172 & 292.1185 & -0.0013 \\
\hline & $\mathrm{C}_{14} \mathrm{H}_{21} \mathrm{~N}_{2} \mathrm{O}_{3}$ & 265.1542 & 265.1552 & -0.0010 \\
\hline & $\mathrm{C}_{14} \mathrm{H}_{18} \mathrm{NO}_{3}$ & 248.1285 & 248.1287 & -0.0002 \\
\hline & $\mathrm{C}_{12} \mathrm{H}_{18} \mathrm{NO}_{2}$ & 208.1338 & 208.1338 & 0.0000 \\
\hline & $\mathrm{C}_{11} \mathrm{H}_{14} \mathrm{NO}_{2}$ & 192.1014 & 192.1025 & -0.0011 \\
\hline & $\mathrm{C}_{12} \mathrm{H}_{15} \mathrm{O}_{2}$ & 191.1063 & 191.1065 & -0.0002 \\
\hline & $\mathrm{C}_{9} \mathrm{H}_{12} \mathrm{~N}$ & 134.0968 & 134.0970 & -0.0002 \\
\hline
\end{tabular}

\begin{tabular}{|c|c|c|c|c|}
\hline & $\mathrm{C}_{9} \mathrm{H}_{9}$ & 117.0692 & 117.0695 & -0.0003 \\
\hline \multirow{8}{*}{ DP1 } & $\mathrm{C}_{26} \mathrm{H}_{35} \mathrm{~N}_{2} \mathrm{O}_{5}$ & 455.2543 & 455.2546 & -0.0003 \\
\hline & $\mathrm{C}_{14} \mathrm{H}_{21} \mathrm{~N}_{2} \mathrm{O}_{3}$ & 265.1542 & 265.1552 & -0.0010 \\
\hline & $\mathrm{C}_{14} \mathrm{H}_{18} \mathrm{NO}_{3}$ & 248.1285 & 248.1287 & -0.0002 \\
\hline & $\mathrm{C}_{12} \mathrm{H}_{18} \mathrm{NO}_{2}$ & 208.1338 & 208.1338 & 0.0000 \\
\hline & $\mathrm{C}_{11} \mathrm{H}_{14} \mathrm{NO}_{2}$ & 192.1014 & 192.1025 & -0.0011 \\
\hline & $\mathrm{C}_{12} \mathrm{H}_{15} \mathrm{O}_{2}$ & 191.1063 & 191.1065 & -0.0002 \\
\hline & $\mathrm{C}_{9} \mathrm{H}_{12} \mathrm{~N}$ & 134.0968 & 134.0970 & -0.0002 \\
\hline & $\mathrm{C}_{9} \mathrm{H}_{9}$ & 117.0692 & 117.0695 & -0.0003 \\
\hline \multirow{5}{*}{ DP2 } & $\mathrm{C}_{15} \mathrm{H}_{21} \mathrm{~N}_{2} \mathrm{O}_{5}$ & 309.1441 & 309.1450 & -0.0009 \\
\hline & $\mathrm{C}_{15} \mathrm{H}_{18} \mathrm{NO}_{5}$ & 292.1172 & 292.1185 & -0.0013 \\
\hline & $\mathrm{C}_{14} \mathrm{H}_{21} \mathrm{~N}_{2} \mathrm{O}_{3}$ & 265.1542 & 265.1552 & -0.0010 \\
\hline & $\mathrm{C}_{14} \mathrm{H}_{18} \mathrm{NO}_{3}$ & 248.1285 & 248.1287 & -0.0002 \\
\hline & $\mathrm{C}_{11} \mathrm{H}_{14} \mathrm{NO}_{2}$ & 192.1014 & 192.1025 & -0.0011 \\
\hline \multirow{4}{*}{ DP3 } & $\mathrm{C}_{12} \mathrm{H}_{18} \mathrm{NO}_{2}$ & 208.1338 & 208.1338 & 0.0000 \\
\hline & $\mathrm{C}_{12} \mathrm{H}_{15} \mathrm{O}_{2}$ & 191.1063 & 191.1065 & -0.0002 \\
\hline & $\mathrm{C}_{9} \mathrm{H}_{12} \mathrm{~N}$ & 134.0968 & 134.0970 & -0.0002 \\
\hline & $\mathrm{C}_{9} \mathrm{H}_{9}$ & 117.0692 & 117.0695 & -0.0003 \\
\hline \multirow{5}{*}{ DP4 } & $\mathrm{C}_{20} \mathrm{H}_{27} \mathrm{~N}_{2} \mathrm{O}_{7}$ & 407.1819 & 407.1818 & +0.0001 \\
\hline & $\mathrm{C}_{19} \mathrm{H}_{27} \mathrm{~N}_{2} \mathrm{O}_{5}$ & 363.1918 & 363.1920 & -0.0002 \\
\hline & $\mathrm{C}_{14} \mathrm{H}_{21} \mathrm{~N}_{2} \mathrm{O}_{3}$ & 265.1542 & 265.1552 & -0.0010 \\
\hline & $\mathrm{C}_{14} \mathrm{H}_{18} \mathrm{NO}_{3}$ & 248.1285 & 248.1287 & -0.0002 \\
\hline & $\mathrm{C}_{5} \mathrm{H}_{10} \mathrm{NO}_{2}$ & 116.0711 & 116.0712 & -0.0001 \\
\hline \multirow{3}{*}{ DP5 } & $\mathrm{C}_{15} \mathrm{H}_{18} \mathrm{NO}_{5}$ & 292.1172 & 292.1185 & -0.0013 \\
\hline & $\mathrm{C}_{14} \mathrm{H}_{18} \mathrm{NO}_{3}$ & 248.1285 & 248.1287 & -0.0002 \\
\hline & $\mathrm{C}_{11} \mathrm{H}_{14} \mathrm{NO}_{2}$ & 192.1014 & 192.1025 & -0.0014 \\
\hline
\end{tabular}

Table 1: Elemental compositions of daughter ions of MOX (m/z 499), DP1 (m/z 455), DP2 (m/z 309), DP3 (m/z 407), DP4 (m/z 407), DP5 $(\mathrm{m} / \mathrm{z} 292)$.

\section{Characterization of MOX and its DPs using LC-MS/MS}

\section{MS/MS of MOX}

The positive ion ESI-MS of MOX shows an abundant $[\mathrm{M}+\mathrm{H}]^{+}$ion at $\mathrm{m} / \mathrm{z}$ 499. Its $\mathrm{MS} / \mathrm{MS}$ spectrum (Figure $3 \mathrm{a}$ ) shows product ions at $\mathrm{m} / \mathrm{z}$ 455 (loss of $\mathrm{CO}_{2}$ ), m/z 309 (protonated 2-(2-aminopropanoyl)-6,7dimethoxy-1,2,3,4-tetrahydroisoquinoline-3-carboxylic acid), m/z 292 (loss of $\mathrm{NH}_{3}$ from $\mathrm{m} / \mathrm{z} 309$ ), $\mathrm{m} / \mathrm{z} 265$ (protonated 2-amino-1-(6,7dimethoxy-3,4-dihydroisoquinolin-2(1H)-yl)propan-1-one), m/z 248 (loss of $\mathrm{NH}_{3}$ from $\mathrm{m} / \mathrm{z}$ 265), $\mathrm{m} / \mathrm{z} 208$ (protonated ethyl 2-amino-4phenylbutanoate), $\mathrm{m} / \mathrm{z} \quad 192$ (protonated 6,7-dimethoxy-1,4dihydroisoquinoline), $\mathrm{m} / \mathrm{z} 191$ (loss of $\mathrm{NH}_{3}$ from m/z 208), m/z 134 (protonated 3-phenylprop-1-en-1-amine) and m/z 117 (loss of $\mathrm{NH}_{3}$ 
Citation: Babu KBR, Nagaraju P, Rajendra, Sankar DG, Rao JVLNS, et al. (2018) Identification and Characterization of Forced Degradation Products of Moexipril Using LC-ESI-MS/Q-TOF. Biochem Anal Biochem 7: 356. doi:10.4172/2161-1009.1000356

Page 4 of 6

from $\mathrm{m} / \mathrm{z}$ 134). The proposed fragmention mechanism for protonated MOX is shown in Figure 4. The most probable structures are proposed for the fragment ions based on accurate mass measurements (Table 1).
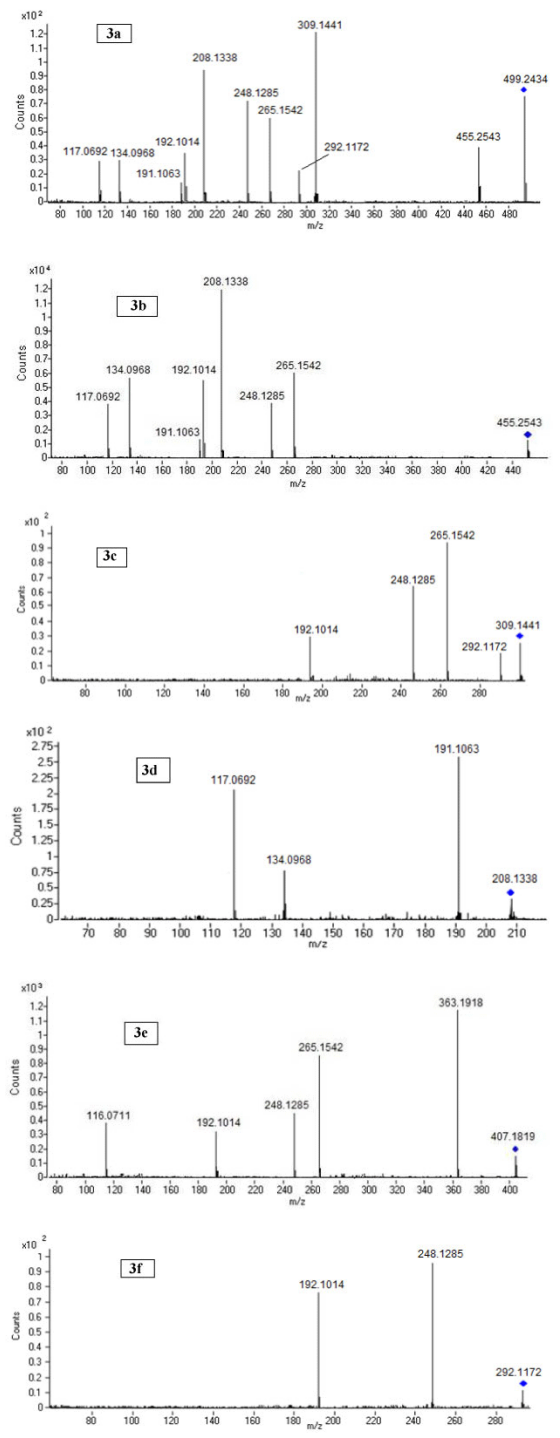

Figure 3: (a) ESI-MS/MS spectrum of $[\mathrm{M}+\mathrm{H}]^{+}$ion $(\mathrm{m} / \mathrm{z}$ 499) of MOX (b) ESI-MS/MS spectrum of $[\mathrm{M}+\mathrm{H}]^{+}$ion $(\mathrm{m} / \mathrm{z} 455)$ of DP1 (c) ESI-MS/MS spectrum of $[\mathrm{M}+\mathrm{H}]^{+}$ion $(\mathrm{m} / \mathrm{z} 309)$ of DP2 (d) ESIMS/MS spectrum of $[\mathrm{M}+\mathrm{H}]^{+}$ion $(\mathrm{m} / \mathrm{z} 208)$ of DP3 (e) ESI-MS/MS spectrum of $[\mathrm{M}+\mathrm{H}]^{+}$ion $(\mathrm{m} / \mathrm{z}$ 407) of DP4 (f) ESI-MS/MS spectrum of $[\mathrm{M}+\mathrm{H}]^{+}$ion $(\mathrm{m} / \mathrm{z} 292)$ of DP5.

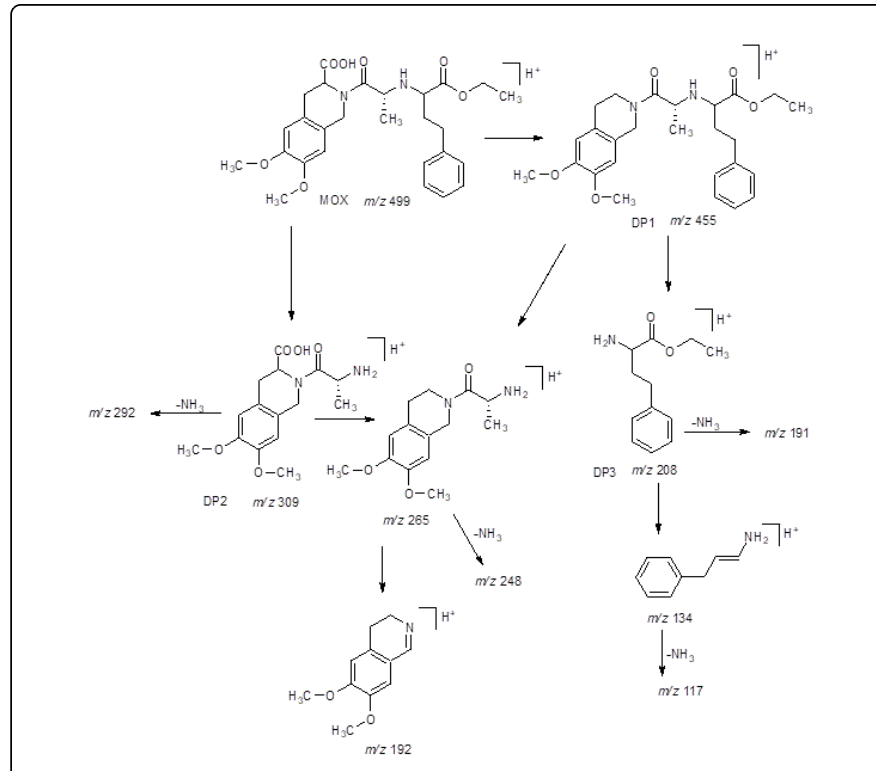

Figure 4: Proposed fragmentation pattern for protonated MOX, DP1, DP2 and DP3.

\section{MS/MS of degradation products}

All the DPs DP1-DP5 were eluted within 15 minutes on C-18 column. Table 2 provides information on the retention times (Rt) and elemental composition of these Dps. Figure 1 shows the proposed structures of all the Dps. The DPs were characterized by performing LC-ESI-MS/MS experiments. The elemental composition of all the DPs and their fragment ions were confirmed by accurate mass measurements.

DP1 ( $\mathrm{m} / \mathrm{z}$ 455): The degradation product DP1 at m/z 455.2543 ([M $\left.+\mathrm{H}]^{+} ; \mathrm{C}_{26} \mathrm{H}_{35} \mathrm{~N}_{2} \mathrm{O}_{5}\right)$ was eluted at 11.9 min under acidic, neutral and oxidative stress conditions. The LC-ESI-MS/MS spectrum (Figure $3 \mathrm{~b}$ ) of protonated DP1 shows product ions at $\mathrm{m} / \mathrm{z} 248$ (protonated 1-(6,7dimethoxy-3,4-dihydroisoquinolin-2(1H)-yl)prop-2-en-1-one), $\mathrm{m} / \mathrm{z}$ 208 (protonated ethyl 2-amino-4-phenylbutanoate), $\mathrm{m} / \mathrm{z} \quad 192$ (protonated 6,7-dimethoxy-3,4-dihydroisoquinoline), and $\mathrm{m} / \mathrm{z} 191$ (protonated ethyl 4-phenylbut-2-enoate). The proposed fragmentation mechanism for protonated DP1 is shown in Figure 4. From the structure of MOX, DP1 can be assigned the structure, ethyl 2-(1-(6,7dimethoxy-3,4-dihydro iso-quinolin-2(1H)-yl)-1-oxopropan-2ylamino)-4-phenyl butanoate. Table 1 gives the accurate mass measurements data which supports the fragmentation of protonated DP1.

\begin{tabular}{|c|c|c|c|c|c|c|c|}
\hline $\begin{array}{l}\text { MOX and } \\
\text { DPs }\end{array}$ & Rt $(\min )$ & Proposed formula & $\begin{array}{l}\text { Observed mass } \\
(\mathrm{Da})\end{array}$ & $\begin{array}{l}\text { Calculated mass } \\
(\mathrm{Da})\end{array}$ & Error (Da) & $\begin{array}{l}\text { Proposed } \\
\text { elemental loss }\end{array}$ & MS/MS fragment ions \\
\hline MOX & 7.6 & $\mathrm{C}_{27} \mathrm{H}_{35} \mathrm{~N}_{2} \mathrm{O}_{7}$ & 499.2434 & 499.2444 & -0.0010 & --- & $\begin{array}{l}455,309,292,265,248, \\
208,192,191,134,117\end{array}$ \\
\hline DP1 & 11.9 & $\mathrm{C}_{26} \mathrm{H}_{35} \mathrm{~N}_{2} \mathrm{O}_{5}$ & 455.2543 & 455.2546 & -0.0003 & $\mathrm{CO}_{2}$ & $\begin{array}{l}265,248,208,192,191, \\
134,117\end{array}$ \\
\hline
\end{tabular}


Citation: Babu KBR, Nagaraju P, Rajendra, Sankar DG, Rao JVLNS, et al. (2018) Identification and Characterization of Forced Degradation Products of Moexipril Using LC-ESI-MS/Q-TOF. Biochem Anal Biochem 7: 356. doi:10.4172/2161-1009.1000356

Page 5 of 6

\begin{tabular}{|l|l|l|l|l|l|l|l|}
\hline DP2 & 1.7 & $\mathrm{C}_{15} \mathrm{H}_{21} \mathrm{~N}_{2} \mathrm{O}_{5}$ & 309.1441 & 309.1450 & -0.0009 & $\mathrm{C}_{12} \mathrm{H}_{14} \mathrm{O}_{2}$ & $292,265,248,192$ \\
\hline DP3 & 5.7 & $\mathrm{C}_{12} \mathrm{H}_{18} \mathrm{NO}_{2}$ & 208.1338 & 208.1338 & 0.0000 & $\mathrm{C}_{15} \mathrm{H}_{17} \mathrm{NO}_{5}$ & $191,134,117$ \\
\hline DP4 & 8.6 & $\mathrm{C}_{20} \mathrm{H}_{27} \mathrm{~N}_{2} \mathrm{O}_{7}$ & 407.1819 & 407.1818 & 0.0001 & $\mathrm{C}_{7} \mathrm{H}_{8}$ & $363,265,248,192,116$ \\
\hline DP5 & 9.1 & $\mathrm{C}_{15} \mathrm{H}_{18} \mathrm{NO}_{5}$ & 292.1171 & 292.1185 & -0.0014 & $\mathrm{C}_{12} \mathrm{H}_{17} \mathrm{NO}_{2}$ & 248,192 \\
\hline
\end{tabular}

Table 2: Elemental compositions of MOX and its DPs (DP1-DP5).

DP2 (m/z 309): The degradation product DP2 formed under acidic and basic conditions was eluted at $1.7 \mathrm{~min}$. The LC-ESI-HRMS spectrum showed its $[\mathrm{M}+\mathrm{H}]^{+}$at $\mathrm{m} / \mathrm{z} 309.1441$ with an elemental composition of $\mathrm{C}_{15} \mathrm{H}_{21} \mathrm{~N}_{2} \mathrm{O}_{5}$. Its MS/MS spectrum (Figure $3 \mathrm{c}$ ) shows product ions at $\mathrm{m} / \mathrm{z} 292$ (loss of $\mathrm{NH}_{3}$ ), $\mathrm{m} / \mathrm{z} 265$ (loss of $\mathrm{CO}_{2}$ ), $\mathrm{m} / \mathrm{z} 248$ (loss of $\mathrm{NH}_{3}$ from m/z 265), m/z 192 (protonated 6,7-dimethoxy-1,4dihydroisoquinoline). The proposed fragmentation mechanism for protonated DP2 is shown in Figure 4. The fragmentation of DP2 giving rise to all the structure indicative ions, is highly compatible with the proposed structure, 2-(2-aminopropanoyl)-6,7-dimethoxy-1,2,3,4tetrahydroisoquinoline-3-carboxylic acid.

DP3 (m/z 208): The degradation product DP3 at $\mathrm{m} / \mathrm{z} 208.1338$ ([M $+\mathrm{H}]^{+}$) formed under basic stress conditions, with an elemental composition of $\mathrm{C}_{12} \mathrm{H}_{18} \mathrm{NO}_{2}$ was eluted at $5.7 \mathrm{~min}$. The LC-ESI-MS/MS spectrum (Figure $3 \mathrm{~d}$ ) of protonated DP3 shows product ions at $\mathrm{m} / \mathrm{z}$ 191 (loss of $\mathrm{NH}_{3}$ ), m/z 134 (protonated 3-phenylprop-1-en-1-amine) and $\mathrm{m} / \mathrm{z} 117$ (loss of $\mathrm{NH}_{3}$ from $\mathrm{m} / \mathrm{z}$ 134). The proposed fragmentation mechanism for protonated DP3 is shown in Figure 4. The observed characteristic fragmentation is found to be consistent with the structure, ethyl 2-amino-4-phenylbutanoate.

DP4 (m/z 407): The degradation product DP4 at m/z 407.1819 ([M $+\mathrm{H}]^{+}$) formed under hydrolytic, oxidative and photolytic stress with an elemental composition of $\mathrm{C}_{20} \mathrm{H}_{27} \mathrm{~N}_{2} \mathrm{O}_{7}$ was eluted at $8.6 \mathrm{~min}$. The LCESI-MS/MS spectrum (Figure $3 \mathrm{e}$ ) shows product ions at $\mathrm{m} / \mathrm{z} 363$ (loss of $\left.\mathrm{CO}_{2}\right), \quad \mathrm{m} / \mathrm{z} 265$ (protonated 2-amino-1-(6,7-dimethoxy-3,4dihydroisoquinolin-2(1H)-yl)propan-1-one), $\mathrm{m} / \mathrm{z} 248$ (loss of $\mathrm{NH}_{3}$ from $\mathrm{m} / \mathrm{z}$ 265), $\mathrm{m} / \mathrm{z} 192$ (protonated 6,7-dimethoxy-1,4dihydroisoquinoline) and $\mathrm{m} / \mathrm{z} 116$ (protonated ethyl 2-aminoacrylate). The proposed fragmentation mechanism for protonated DP4 is shown in Figure 5. Based on accurate mass measurements (Table 1), the structure of DP4 was assigned as, 2-(3-ethoxy-3-oxoprop-1-en-2ylamino) propanoyl)-6,7-dimethoxy-1,2,3,4-tetrahydro isoquinoline-3-carboxylic acid.

DP5 ( $\mathrm{m} / \mathrm{z}$ 292): The degradation product DP5 formed in acidic, neutral, oxidative and photolytic stress conditions was eluted at 9.1 min. The LC-ESI-HRMS spectrum showed its $[\mathrm{M}+\mathrm{H}]^{+}$at $\mathrm{m} / \mathrm{z}$ 292.1171 with an elemental composition of $\mathrm{C}_{15} \mathrm{H}_{18} \mathrm{NO}_{5}$. Its MS/MS spectrum (Figure 3f) shows product ions at $\mathrm{m} / \mathrm{z} 248$ (loss of $\mathrm{CO}_{2}$ ) and $\mathrm{m} / \mathrm{z} 192$ (protonated 6,7-dimethoxy-1,4-dihydroisoquinoline). The proposed fragmentation mechanism for protonated DP5 is shown in Figure 6. The observed characteristic fragmentations are keeping in line with the proposed structure, 2-acryloyl-6,7-dimethoxy-1,2,3,4tetrahydroisoquinoline-3-carboxylic acid. 
Citation: Babu KBR, Nagaraju P, Rajendra, Sankar DG, Rao JVLNS, et al. (2018) Identification and Characterization of Forced Degradation Products of Moexipril Using LC-ESI-MS/Q-TOF. Biochem Anal Biochem 7: 356. doi:10.4172/2161-1009.1000356

Page 6 of 6

\section{References}

1. ICH Harmonised Tripartite Guideline (2003) Stability Testing of New Drug Substances and products. International Conference on Harmonization of Technical Requirements of Pharmaceuticals for Human Use .

2. WHO (2007) Draft stability testing of Active Pharmaceutical Ingredients and Pharmaceutical products. World Health Organization, Geneva, Switzerland.

3. Therapeutic products Directorate (2003) Guidance for Industry Stability Testing of Existing Drug Substances and Products. Therapeutic products Directorate, Canada.

4. Hochadel M, Avom J, Thomas WH, Greider K (2005) The AARP guide to pills. Sterling, London, England.

5. Chrysant SG, Chrysant GS (2004) Pharmacological and Clinical Profile of moexipril: A Concise Review. Journal clin Pharm 44: 827-836.
6. Elshanawane AA, Mostafa SM, Elgawish MS (2008) Application of a Validated, Stability indicating LC Method to Stress Degradation studies of Ramipril and Moexipril.HCl. Chromatographia 67: 567-573.

7. Koti J, Hada V, Petroianu G, Hasan M Y, Tekes K, et al. (2006) Monitoring the Metabolism of Moexipril to Moexiprilat Using High Performance Liquid Chromatography - Electrospray Ionization Mass Spectrometry. J Chromatogr Sci 44: 214-218.

8. Hammes W, Hammes B, Buchsler U, Paar F, Bokens H (1995) Simultaneous determination of Moexipril and Moexiprilat, its active metabolite, in human plasma by gas chromatography-negative ion chemical ionization mass spectrometry. J Chromatogr B Biomed Appl 670: 81-89.

9. Vijaya VK, Ramesh M, Nageshwara RP, Jaswanth KI, Vas BV, et al. (2012) A rapid and sensitive liquid chromatography- tandem mass spectrometric assay for moexipril, an angiotensin converting enzyme inhibitor in human plasma. Biomedical chromatography 26: 1552-1558. 